\title{
THE CORPORATE GOVERNANCE CONTRIBUTION AS A CREATION OF VALUE FOR COMMERCIAL PARTNERSHIPS BETWEEN SERVICE PROVIDERS AND LOGISTIC OPERATORS
}

Carlos Alberto da Rocha Uninove - Nine of July University, Brazil E-mail: carlosar.ops@terra.com.br

Orlando Roque da Silva FMU - Laureate International Universities, Brazil

E-mail: orlandoroque@uol.com.br

Alessandro Marco Rosini FMU - Laureate International Universities, Brazil E-mail: alessandro.rossini@yahoo.com

Submission: 07/09/2016

Revision: 28/06/2017 Accept: 13/07/2017

\section{ABSTRACT}

This theoretical research on a case study in American Company identified the possibility of Governance factors contributing as evidence of value in the relationships of commercial partnerships between Logistic Operator and service providers. The analysis of data allowed to conclude and identify three possible levels of grouping of partnerships due to variables of facilitators that showed it possible to have this relationship with transparency between client and suppliers. Most of the analyzed groups of suppliers were characterized by the interest of sharing operating profits with the client company in short-term contracts and little tolerance to financial risks of joint investments in future contracts. Transparency, ethics and corporate responsibility, pillars of Corporate Governance, contributed to the definition of these groupings of partnerships, besides consolidating the aspects of mutual and evolutionary trust between companies.

Keywords: Corporate Governance Aspects, Partnership Agreement, Logistics Operators, Providers 
DOI: 10.14807/ijmp.v9i1.683

\section{INTRODUCTION}

The requirement of companies to integrate into international trade and the expansions of financial and commercial transactions on a global scale have made Corporate Governance studies relevant to organizations that, when followed by companies, result in benefits and return on investments to shareholders and investors who is it them, to looking for to maximize profits and monitor the management position (IBGC, 2009).

These actions on aspects of governance are important for logistics sectors it such as services, which operates in logistics because can be sure that the transparent has followed it all commercial process from the beginning without fraud because misconduct of its agents in negotiations with the provider that approval these partnerships. Thus, and however this the aspects of Corporate Governance help to make these processes transparent and to assure the Stakeholders and Shareholders that the agents that represent them in the decision making for acted in accordance with the legal principles of transparency and ethics.

So, the aim of this investigation is to establish that as long as Corporate Governance principles are followed, contracts will be signed with transparency, ethics and corporate responsibility between logistical operators and service providers in which the representatives of these companies now have a safeguard against fraud misconduct and conflicts of interest of agents to formalize high-value investment partnership agreements where it is certainly the main contribution of these studies.

In this way then these relationships are business-to-business and come together to make it to easier for contracts for business prospecting and business partnerships to be made transparent and ethical between companies.

With this understanding the research investigates whether the perception of the value of corporate governance positively influences the companies so that they can validate contracts of commercial partnerships and validate contracts with mutual investments to share joint profits in the short and long term with the logistics provider besides verifying aspects of trainers and drivers to contribute to this relationship being consolidated in which these are the main problem of this study. 
DOI: 10.14807/ijmp.v9i1.683

\section{CORPORATE GOVERNANCE FUNDAMENTALS}

As instructed the IBGC (2009), the term of corporate governance is designed to establish rules governing the relationship between businesses and the interests of shareholders and managers (IBGC, 2009).

For Domeneghetti and Meir (2009), the Corporate governance can be considered as one of the most important and valuable objects of a company, assuming that the principles of conduct and best practices can make them more competitive, favoring better long term results.

The culture of critical management is essential to the practice of governance, but should be carried out with ethics, transparency, trust between agents and proprietors, with exemplary counsel and diverse membership that act for shareholders and "stakeholders" adding value simultaneously for both.

Although private companies do not have a specific governance code, the laws for public companies define guidelines related to the composition and duties of the board of directors, supervisory board and executive board. It is observed that this ownership structure is determined to board composition of directors and advisors to meet the needs of its drivers.

Issues such as risk values for enterprises, level of motivation of its employees, loyalty against competitors, threats satisfaction and loyalty contracts, strategies for a culture of trust and improve relations between board members, shareholders, agents, administrators and other stakeholders need to be addressed when thinking about governance (HILB, 2005).

As informed in the IBGC (2009), the board of directors acts as a mediator with control mechanisms to protect the interests of shareholders that accompany the management of agents in decision-making position, and is the protection of investor interests. The assignments demonstrate that the board is the main component of a governance system as it is responsible for the decisions of the strategic direction of the company. In accordance with to the IBGC (2010), the pillars of Corporate Governance are transparency, fairness, accountability and corporate responsibility. 


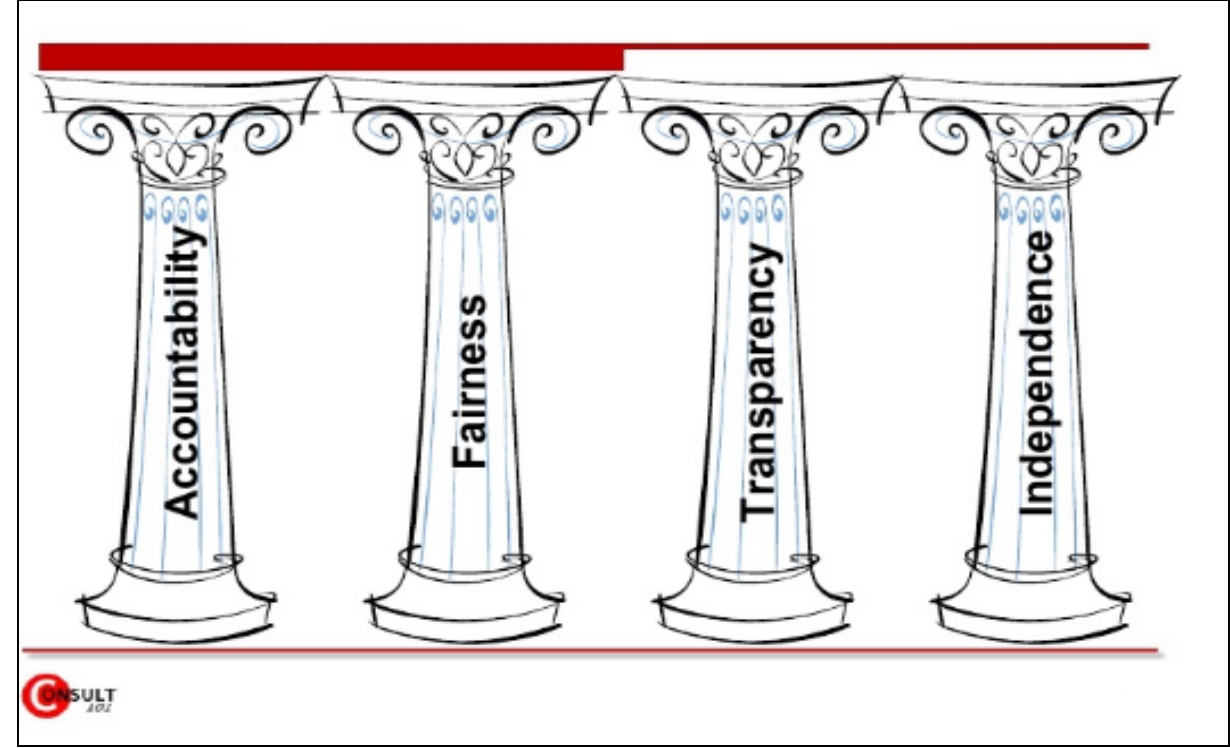

Figure 1: Pillars of Corporate Governance

Source: Lean Transformation Consultan (LEAN) 2009

The principle of transparency should ensure that they are provided to "stakeholder's" information of interest in a balanced way, with quality, clarity, timeliness and accessible language, prevailing substance over form, and allowing for a correct understanding of the organization (IBGC, 2009). It notes that this principle is present in organizations by the essence of the company and is regulated by government agencies.

Accountability (accountability) states that agents in the management position when they make decisions, they must account for their actions in full, of the acts who practice or omissions that may occur and create risks to shareholders.

Fairness is characterized by fair treatment of all shareholders and other stakeholders, the stakeholders (IBGC, 2009).

Corporate responsibility assumes that agents in management position to make decisions with transparency and ethics, and taking steps to ensure the sustainability of organizations to ensure longevity of companies, incorporating social considerations and the principle of governance.

Models of corporate governance in organizations are of the insider system: high concentration of companies with shared control family with few investors, ownership structure with high concentration of common shares and high emission rate preferred shares. 
INDEPENDENT JOURNAL OF MANAGEMENT \& PRODUCTION (IJM\&P)

http://www.ijmp.jor.br

v. 9, n. 1, January - March 2018

ISSN: 2236-269X

DOI: 10.14807/ijmp.v9i1.683

It notes the existence of minority shareholders very active, high overlap between ownership and management with little clarity, guidelines between the roles of the board and management with a shortage of professional counselors, and no committees responsible for specific issues (IBGC, 2009).

\section{LOGISTICS OPERATORS, SUPPLY CHAIN AND LOGISTICS PARTNERSHIP}

In Brazil, the term Logistics Operator comes from the concept of logistics service outsourcing (outsourcing) or logistics contract (LIEB; RANDAL, 1996) that emerged in the USA in the eighties, and today is strongly widespread in European countries the nomenclature of Third-Party Logistic Provider.

The Logistics provider's definitions that have arisen in recent years in Brazil, are several. As informed from the Brazilian association of handling Logistics (ABML), the Logistics provider is a logistics service provider that specializes in the management of logistics operations activities, or part of the various stages of the (Supply Chain), adding value to stored products of its customers, with the power to at least simultaneously provide services in three activities: inventory control, warehousing and transportation management.

As it says the Fleury and Ribeiro (2001), a logistics company will only be considered as a logistics operator in that it can provide the three basic activities: warehouse management, information system, operation and management transport for distribution of products, and have a solid and transparent relationship of business partnerships with their suppliers.

To Christopher (2001), logistics is the strategic management in obtaining, handling and storing stocks of materials, finished products, and distribution and marketing channels all contribute to the organization's profitability.

As the Logistics Operations provider in addition to brand credibility and transparent management with suppliers, they highlight the need for loyalty and formalization of contracts of commercial partnerships with service providers, and good corporate governance practices for approval supply that can add value in the commercial relationship.

Lambert, Emmelhainz and Gardner (1999) defines partnership like the transactions based on mutual trust, transparency, sharing of risks and benefits, providing a competitive advantage to the organization. 
INDEPENDENT JOURNAL OF MANAGEMENT \& PRODUCTION (IJM\&P)

http://www.ijmp.jor.br

v. 9, n. 1, January - March 2018

ISSN: 2236-269X

DOI: 10.14807/ijmp.v9i1.683

The contractual form of partnerships between companies has emphasis on the degree of detail and the time. Trust is associated with reputation and relationship process over time. Williamson (1985) suggests that opportunistic behavior tends to disappear if the parties are more transparent and ethical.

For Larentis, Antonello and Slongo (2010), relations between organizations rely on the relationship between people who support and understand the complexity of the actions and strategies of companies, and develop a standard management process in the supply chain (Supply Chain).

As pointed out by Lambert and Cooper (2000), the evolution of interest in understanding the management of the supply chain lies in the argument that companies do not compete separately, but jointly by creating relationships that can consolidate and generate partnerships.

To Cislaghi et al (2014), the commercial relationships are not based only on resources investments and selecting the best search commercial partners, but also the aspects that involve trust, loyalty, commitment, exchange of information, cooperation and understanding relationship value among companies. To the extent that commercial partnerships with logistics operators are formed based on ethics, transparency, trust and loyalty between companies, it is found positive results in providing services and suppliers throughout the supply chain.

Providers should understand that governance aspects are for the logistics operator one way the partnership to be solid it. Points to care: The recognition of good conduct and commitment to ethics, transparency between companies to conduct business with corporate responsibility, customer recognition, credibility for the emergence of partnerships, new business opportunities in other segments for provider's services, and does not create risks for shareholders and investors.

The growth of the logistics operations depends on the Logistics Operators investment to optimize the Supply Chain and attracting new customers, who are demanding quality, productivity, security of stored products and risk of malfunctions and product theft where's is to clear that Corporate Governance are very important it for this relationship.

As reported to La Londe and Cooper (1989) and Bowersox et al (1989), risk sharing and benefit appears as a factor in the construction of logistics partnerships, 
and must do with the concept of fair division and benefits the contractual rules, emerging confidence as the main indicator and decisive for partnerships between companies.

Frankema and Costa (2005) and Möllering (2005) point out that control and trust are shown entwined in relations between companies, and favor the predictability of the actions of the actors involved and, consequently, reducing the risk of losses on transactions performed.

\section{RESEARCH METHODOLOGY PROCEDURES}

The object of this study companies are originally American and European global, being the first based in the United States of America, and the second in France. Both companies boast expertise in solutions in the Supply Chain for the provision of logistics services. The American company has been on the market for more than a century, and the French company for 58 years.

The European company came to Brazil in the second half of 2013 through acquisition of subsidiary and American competitor, which is part of this study and worked in the country for over 17 years. Overall, the French buyer, considering all the subsidiaries of the group in the world in the year 2014, presented a turnover reported by the Board of Director of 3 billion Euros and had approximately 15000 commercial partners in Brazil close to 2000. The group is supported by a conglomerate of more than 20000 employees on a global scale. In Brazil this figure is around 1300 employees.

So this research is characterized by a case study in the group described here.

The main activities carried out in the country are, and innovation in the Supply Chain with the optimization of the logistics operations, warehousing and distribution of products, to increase productivity in areas moving to palletized loads, copacking and transport products already present in other countries. To accomplish all this operating cycle endorses service providers for quality aspects, commercial partnerships and adoption of best practices of corporate governance to basically follow transparency, ethics and corporate responsibility of its agents.

For global governance policy issues of confidentiality in the whole group, the company does not authorize disclosure of the business by means of communication 
is written or spoken, and not the names of service providers, business partners and customers.

\subsection{Questionnaire applied}

The research methodology using quantitative and descriptive analysis. A structured questionnaire with close-ended questions is used in data collection. In this manner, structured questionnaire was sent to 30 contractors with profile for commercial partnerships. The sample is random and not for convenience, although it is known that the sample size is small.

The application of the questionnaire (see attachment) was a descriptive study that sought to identify the perception of value on good practices of corporate governance among service providers and logistic operators, in so far as assumptions such as transparency, ethics and corporate responsibility generate value for the consolidation of commercial partnerships, as well as drivers and facilitators that could allow this kind of rapprochement and integration between the companies.

The questionnaire consists of 20 questions about the values and governance factors that direct and facilitate the physical approach to the business relationship. Each question has a weight and scoring scale to enable standardization of analysis with statistical inference, which allowed the answers, as model below.

\section{2. definition and selection of variables in Likert Scales}

The data collection instrument was based on the theory of Lambert, Emmelhainz and Gardner (1996) and included 4 drivers and 4 facilitators for business partnerships between companies and governance aspects.

(A). Drivers: Values that nurture and encourage business partnerships;

(B). Facilitators: Organizational Factors that influence the development of partnerships.

Table 1: "Drivers" and "Facilitators" to commercial partnership and loyalty contracts

\begin{tabular}{|c|c|}
\hline Perception/Constructs & Variables \\
\hline $\begin{array}{c}\text { A. Drivers (adapted from } \\
\text { LAMBERT; EMMELHAINZ; }\end{array}$ & $\begin{array}{c}\text { 1. What is the probability of the partnership have } \\
\text { GARDNluence only in the cost presented in the } \\
\text { business proposal and aspects of governance? }\end{array}$ \\
$\begin{array}{c}\text { A.1. MOTIVATOR CONTRIBUTE TO } \\
\text { COMMERCIAL PARTNERSHIP }\end{array}$ & $\begin{array}{c}\text { 2. what is the probability of commercial partnership } \\
\text { for the service generate new business in other } \\
\text { clients? }\end{array}$ \\
\cline { 2 - 2 } & 3. what is the probability of commercial partnership to \\
\hline
\end{tabular}




\begin{tabular}{|c|c|}
\hline & $\begin{array}{l}\text { open new service provider customers in different } \\
\text { segments of the logistics industry? }\end{array}$ \\
\hline & $\begin{array}{l}\text { 4. what is the probability of commercial partnership to } \\
\text { consolidate long-term and on up to five (5) } \\
\text { years? }\end{array}$ \\
\hline \multirow[t]{4}{*}{$\begin{array}{l}\text { B. Facilitators (adapted from } \\
\text { LAMBERT; EMMELHAINZ; GARDNER, } \\
\text { 1996) }\end{array}$} & $\begin{array}{l}\text { 5. What is the probability of the companies have } \\
\text { similar organizational cultures following } \\
\text { instruments such as those of ethics, } \\
\text { transparency and corporate responsibility? }\end{array}$ \\
\hline & $\begin{array}{l}\text { 6. What is the probability of the partner and the } \\
\text { operator } \\
\text { Have leadership systems logistics and } \\
\text { organizational philosophies similar Operational } \\
\text { management? }\end{array}$ \\
\hline & $\begin{array}{l}\text { 7. What is the probability of having the service } \\
\text { provider } \\
\text { same criteria for calculation of KPIs and SLAS } \\
\text { Logistic operators }\end{array}$ \\
\hline & $\begin{array}{l}\text { 8. What is the probability of the Logistical Operator } \\
\text { customer loyalty } \\
\text { and consolidate short-term and long-term } \\
\text { contracts on commercial partnership? }\end{array}$ \\
\hline
\end{tabular}

Source: based on Lambert, Emmelhainz and Gardner (1996)

The variables were measured in a range on Likert scale ranging in score of 1 (one) to 5 (five) and $1=0 \%$ probability and $5=100 \%$ probability.

The sum of the scores of drivers and facilitators for business partnership formed the variables used in the analysis of the study and statistical techniques can range from 1 (one) to 5 (five) so that the scores of variables composed of 4 (four) to 20 (twenty). The study also analyzed 12 (twelve) elements of commercial partnerships (operational and managerial) measured on a scale ranging from 1 (one) to 3 (three), 1 = weak, $2=$ moderate $3=$ strong.

Data analyses were made by groups and cross-tabulations, which is a multivariate technique to group data based on a measure of equality, when groups formed homogeneously and heterogeneously, compared to other groups (HAIR et al., 2009).

In the initial analysis of the data was used the method of exploratory sorting to get the best number for groups on empirically. In studies of Lambert, Emmelhainz and Gardner (1996) are suggested the existence of 3 (three) different types of commercial partnerships, one of these groups must contemplate very heterogeneous profiles of the variables of the study (drivers and facilitators) in commercial partnerships. 
The meaning of these different types are respectively:

(a) Type 1: the more favorable facilitators consider the proximity between players is very important, but without interest in exclusivity of supply;

(b) Type 2: does not appreciate the proximity to commercial, because the partnership intends to work exclusively;

(c) Type 3: value the proximity to commercial.

Data were analyzed by the method of sorting by groups of business partnerships, allowing analysis on the structure of the sample profiles of partnerships in which the results have confirmed the method not exploratory way ordering to obtain the optimal number for empirical analysis.

The original study of Lambert, Emmelhainz and Gardner (1996) suggests the existence of 3 (three) types and profiles of different partnerships, even occurring heterogeneous groups in terms of the variables of study of drivers and facilitators for partnerships.

The application of these criteria was in function of the sample being considered too small for only 30 (thirty) business.

The companies' object of this study is from original global American origin, the first based in the United States and have expertise in solutions in the Supply Chain for logistics services. The American company is in the EUA market for more than a century and in Brazil for 17 year.

We can say that the main activities in the country are innovation solutions in the chain of Supply Chain with optimization in the logistics operations on storage, distribution of products and solutions for increase of productivity in areas of handling of palletized loads, packaging of products for transportation and fundamentally to realize Approval of service providers by criteria of punctuality and risk assessment in the delivery of the client's load, besides the adoption of good governance practices such as transparency, ethics and corporate responsibility.

According to the company that provided data for these studies, and for confidentiality reasons do not had it consent it to the sharing this information's of their social reasons and in the same way as service providers which has business partners and customers. 
INDEPENDENT JOURNAL OF MANAGEMENT \& PRODUCTION (IJM\&P)

http://www.ijmp.jor.br

v. 9, n. 1, January - March 2018

ISSN: 2236-269X

DOI: 10.14807/ijmp.v9i1.683

The questionnaire used in collecting information was consented of questions into Governance about aspects values and factors that direct and facilitate the physical approach to the business relationship between enterprises and identified from Corporate Governance values and factors that direct and facilitate the physical approach to the business relationship.

For each question was assigned a weight and scoring scale to allow standardization of analysis with statistical inference.

The instrument for data collection was based on the Lambert theory, Emmelhainz and Gardner (1996), and included four drivers and four facilitators for business partnerships between business and governance aspects. For others driver is it to understand the values that consolidate and motivate business partnerships and facilitators are the organizational factors that influence the development of partnerships.

The research worked three types of commercial partnership where's the commercial partnership type 1 is characterized by show more distant commercial relationships, type 2 partnerships have a more advanced process in the commercial relationship, and type 3 partnerships are more developed in commercial relationships because they are characterized by trust in this relationship and where's it is evidence the governance factors.

Data were analyzed by the ordering method by groups of commercial partnerships that allowed the analysis of the sample structure of the partnerships profiles between logistics operators and suppliers.

\section{ANALYSIS AND FINDINGS}

From a universe of 200 service providers of the Logistics Operator database, only 30 potentially proposed to respond to the survey, with 5 (five) having a (close) correlation to the Logistic Operator's activity and Supply Chain as Warehousing, Labor of Third Parties, Provision of Logistic Services in the audit of freight values, Transportation and Distribution of products, while the others presented conventional supply characteristics with no correlation closer to the logistics operator And end-ofcompany activity, but are prone to the commercial partnership, according to the areas of activity mentioned in the table below. 
INDEPENDENT JOURNAL OF MANAGEMENT \& PRODUCTION (IJM\&P)

http://www.ijmp.jor.br

v. 9, n. 1, January - March 2018

ISSN: 2236-269X

DOI: 10.14807/ijmp.v9i1.683

Table 2: Activity and branches of service of the providers

\begin{tabular}{c|l|l}
\hline Segment Operatestion & Frequency & $\%$ \\
\hline $1 . \quad$ Third- hand services (1) & 3 & $8.50 \%$ \\
\hline 2. Rental of products and services (1) & 2 & $9.30 \%$ \\
\hline 3. Accounting and tax advice & 1 & $3.20 \%$ \\
\hline 4. Logistics distribution solutions (1) & 1 & $4.20 \%$ \\
\hline 5. Commercial properties for rent & 3 & $8.30 \%$ \\
\hline 6. Painting, plastering and building alteration services & 4 & $8.30 \%$ \\
\hline 7. Maintenance of telecommunications and IT equipment & 1 & $3.85 \%$ \\
\hline 8. Infrastructure services of information technology & 1 & $3.85 \%$ \\
\hline 9. Office furniture and furniture & 1 & $3.20 \%$ \\
\hline 10. Battery maintenance services & 1 & $3.10 \%$ \\
\hline 11. Visual communication services & 1 & $3.60 \%$ \\
\hline 12. Provision of direct labor services (1) & Referring to Fig. & $19.80 \%$ \\
\hline 13. Logistics services and auditing of freight rates (1) & 1 & $3.20 \%$ \\
\hline 14. Services of locks mithery and industrial hardware & 1 & $5.20 \%$ \\
\hline 15. Industrial collective meals & 2 & $6.20 \%$ \\
\hline 16. Freight and transport of employees & 1 & $3.00 \%$ \\
\hline 17. Men's and women's uniforms (retail and wholesale) & 1 & $3.20 \%$ \\
\hline & $\Sigma=30$ & $\Sigma=100 \%$ \\
\hline
\end{tabular}

Source: Prepared by the author

Table 2 - Variables of the "drivers" and "facilitators" constructs of the partnerships Construct Variables

Drivers (Adapted from LAMBERT; EMMELHAINZ; GARDNER, 1996) How likely is this relationship between firms to be based solely on cost relation?

What is the likelihood that the business relationship between companies will increase significantly resulting in new business for the company?

What is the probability that the relationship with the contracting company will allow access to prospecting new business with other companies and / or markets different from the current segment?

What is the probability that the business relationship with the contracting company will last in the next 3 (three) years?

Facilitators (Adapted from LAMBERT; EMMELHAINZ; GARDNER, 1996) How likely are the two companies (contractor and contractor) to have similar crops?

How likely are the two companies (contractor and contractor) to present similar operational management systems and philosophies?

What is the probability that the contracting company wishes to develop objectives, targets and KPI (indicators) for the purposes of supply approval? 
How likely is the contractor to have a long-term view of the business relationship?

Table 3: Descriptive statistics Partner grouping Types

\begin{tabular}{llcc}
\hline Supplier Group & & Drivers & Facilitators \\
\hline & Number of cases & 3 & 3 \\
Partnership & Average & 18,0000 & 17,0000 \\
Commercial & Standard deviation & 0,00000 & 0.00000 \\
Type 3 & Coefficient varies & $0 \%$ & $0 \%$ \\
\hline & Number of cases & 19 & 19 \\
Partnership & Average & 18.84025 & 17.23077 \\
Commercial & Standard deviation & 1,36541 & 2.07169 \\
Type 2 & Coefficient varies & $9 \%$ & $14 \%$ \\
\hline Partnership & Number of cases & 2 & 2 \\
Commercial & Average & 10,5000 & 13,5000 \\
Type 1 & Standard deviation & 0,70711 & 2,12132 \\
Favorable & Coefficient varies & $7 \%$ & $16 \%$ \\
Facilitators & Number of cases & 6 & 6 \\
\hline \multirow{2}{*}{ Partnership } & Average & 13.3333 & 10,1667 \\
Commercial & Standard deviation & 1.03280 & 1,16905 \\
Type 1 Favorable & Coefficient varies & $8 \%$ & $11 \%$ \\
Drivers & &
\end{tabular}

Source: Research done

Three service providers showed a propensity for type 3 commercial partnerships, which may indicate a relationship of total trust between companies due to transparency, ethics and corporate responsibility aspects.

This type of partnership configuration, although sustained by long-term contracts, were found in a smaller proportion in the segment, due to the high complexity of the services scopes, as well as the high investment costs involved to consolidate the partnerships between companies.

The other groups were represented in type 1 partner, with two suppliers of this group are less developed, but with more favorable facilitators that the partnerships drivers, which can be an indicator that the agents of the companies in management position tend to keep away the propensity to commercial partnership due to aspects of interorganizational, that can motivate the gap in the commercial relationship in long and short term.

The sample had a predominance of supplier's partnerships with type 2 . This group had $58 \%$ of cases, and was characterized by having median scores for both 
drivers and facilitators, which can be an indicator that these companies have an intermediate level of business relationship supplier customer partnerships under development

What was reported in the previous paragraph has not occurred in the last group with six supplier's similarity of the partnership for type 1 with the most favorable partnerships drivers of the facilitators, which can be an indicator to formalize the commercial partnership but with little approach organizational for development.

Companies with type 3 commercial partnerships value commercial proximity, but with low propensity to exchange organizational and little interest in the joint investment and with interest in the exclusivity of supply.

The companies that had business partnerships type 2 value not proximity between agents (70.2\%), because they intend to work with the partner exclusively. It was noted that the partnership is considered important only for the contractor, no joint investment, there is no exchange of personnel, contracts are short-term, communication between the parties is limited, there is low risk tolerance compared with the type 3 .

Companies that had type 1 trade partner with more favorable facilitators consider the proximity of the very important agents, but no interest in the exclusivity of supply. This makes it difficult to establish a pattern in the elements of the commercial partnership without joint investment, exchange of personnel for shortterm contracts, limited communication, and low risk tolerance.

The study has limitations for not having made possible a comparison with other logistics providers because the number of survey participant's companies was small, which is not possible to generalize the results to the entire population but it was possible to identify the profiles of each group.

It was also possible in accordance with Mazzali and Milan (2006) to showed, type 1 showed low organization and planning for commercial partnerships, the type 3 showed a significant degree of interaction between agents in management position, and type 2 showed an intermediate situation between the two other types.

The boundaries between companies and different types of business partnerships were not rigidly, which can be seen in service provider's suppliers, who 
despite being positioned within a classification in some of the items have characteristics belonging to another group.

It was not possible to say in research that the Logistics Operator may have a systemic view of the entire business partnership and its overall framework spectrum of service provider's suppliers, as shown Machline (2011), and the low interaction with the Service Providers.

About on risk analysis and mutual benefit to share among companies in the commercial partnership it was possible to observe an evolution of type 1 group to type which is close to the proposed Ladeira, Marconatto and Estivalete (2012), which shows the relationship of confidence and risk due to the perception of inter organizational partnership.

In contracts was observed that only companies of type 3 tend to partnerships in the long term, which does not occur in type 1 and 2, which approaches the trust proposal between the parties, as Williamson's proposal (1985), Villena, Revilla and Choi (2011) and Rogan (2013).

This finding shows transparency between companies and indicates the possible existence of aspects and values of corporate governance aspects.

\section{CONCLUSIONS}

Data analysis enabled us to identify that Corporate Governance aspects can be contribute for companies where's which the main contributed was it to relationship for groups to commercial partnership between the Logistics Operator and Service Providers. So most with of suppliers have interest in exclusivity of long and short term supply contracts with logistic operator and intention to share profit and with did not showed different from the other groups of suppliers which as the risk tolerance, showed that both low and average values.

Commercial relationships between service provider's suppliers and logistics operators are current so that:

a) Motivators for to partners in relationships in business partnerships are more important for the characterization of groups that facilitators; 
b) In commercial partnership type 3, lower frequency, there is need for full confidence in inter-organizational relationships, and require more time for consolidation and development;

c) In Type 2 partnerships most companies are in an evolutionary process for commercial partnership, and opportunities in the short-term migration to type 3; and,

d) In the commercial partnership type 1, the motivating drivers of the partnership show that agents in positions for relationship remains distant, and have a low propensity for commercial partnership as facilitators show no more developed partnerships between suppliers and customers.

The study showed the possibility of close trade relationships at different levels between Service Providers and Logistics Operators, for drivers account and proximity facilitators for business partnerships at different levels and types of grouping. As a limitation of study, a small number of respondents.

The study also shows governance aspects such as mutual trust, transparency, ethics and corporate responsibility, which can create more favorable environments for consolidation of strong partnerships in the short and long term.

\section{REFERENCES}

BERNARD, C. B.; SIMON, I. P. (2013) Boardroom strategic decision-making style: understanding the antecedents. Corporate Governance: An International Review. USA: March, v. 21, n. 2, p. 131-146.

BOWERSOX, D. J. et al. (1989) Leading Edge Logistics: Competitive Positioning for the 1990 s Oak Brook (Illinois): Council of Logistics Management.

CHRISTOPHER, M. (2001) Logistics and supply chain management: strategies to reduce costs and improve services. Translation Francisco Roque Monteiro Leite. $2^{\text {a }} 9$ Reprint. 1 The d. São Paulo: Pioneering 2001.

CISLAGHI, T. P.; LARENTIS, F.; GONÇALVES, T.; VILMAR A.; SPERANDIO, G.; DE TONI D. (2014) Contribution of interorganizational relationships for relational performance: a study in dyads focal companies and advisers in foreign trade in the furniture sector. In: ASSOCIATION MEETING OF NATIONAL GRADUATE PROGRAMS IN MANAGEMENT, 28, 2014 Rio de Janeiro. Anais, Rio de Janeiro: ANPAD.

DOMENEGHETTI, D.; MEIER, R. (2009) Intangible assets: the real value of companies. 3. ed. Sao Paulo: Campus.

DRIVE ABML BRAZILIAN ASSOCIATION LOGISTICS (1999) The concept of logistics operator. Tecnologistica. Special Section ABML, year IV, n. 39. 
FLEURY, M. P.; RIBEIRO, A. A. (2001) Logistic Service Providers Industry in Brazil: Featuring the Top Operators. Available in: <Http: //www.cel.coppead.ufrj.br; http: //www.cel.coppead.ufrj.br.http: //www.cel.coppead.ufrj. br.

GARDNER, R. W.; JOHNSON, C. L. (1994) Third-party Logistics in The Logistics. Handbook.

HAIR JR., J. F.; BLACK, W. C.; BABIN, B. J.; ANDERSON, R. E.; TATHAM, R. L. (2009) Análise multivariada de dados. 6 ed. Porto Alegre: Bookman.

HILB, M. (2005) New corporate governance: from good to great practice guidelines. Corporate Governance. Oxford, v. 13, n. 5. p. 569-581.

IBGC - BRAZILIAN INSTITUTE OF CORPORATE GOVERNANCE. (2010) Corporate governance of corporate control structure. Saint Paul Saint Paul, 2009. Corporate governance pillars of corporate governance. Saint Paul Saint Paul,.

LA LONDE, B. J.; COOPER, M. C. (1989) Partnerships in providing customer service: a third-party perspective. Oak Brook, IL: The Council of Logistics Management, 1989.

LADEIRA, W. J.; MARCONATTO, D. A. B.; ESTIVALETE, V. B. (2012) Control to trust? A risk analysis perceived in relationships in a supply chain. Economia \& Management, v. 12, n. 29, p. 98-123. DOI - 10.5752 / P.19846606.2012V12N29P76.

LAMBERT, D. M.; EMMELHAINZ, M. A.; GARDNER, J. T. (1996) Developing and Implementing supply chain partnerships. The International Journal of Logistics Management, v. 7, n. 2, p. 1-17.

LAMBERT, D. M.; EMMELHAINZ, M. A.; GARDNER, J. T. (1996) Building Successful Partnerships Logistics. Journal of Business Logistics, Oak Brook (Illinois), v. 20, no. 1, p. 165-182,

LAMBERT, D. M.; EMMELHAINZ, M. A.; GARDNER, J. T. (1999) Developing and Implementing supply chain partnerships. The International Journal of Logistics Management, v. 7, n. 2, p. 1.

LAMBERT, D. M.; COOPER, M. C. (2000) Issues in Supply Chain Management. Industrial Marketing Management, v. 29, n. 1, p. 65-83.

LARENTIS, F.; ANTONELLO, C. S.; SLONGO, L. A. (2010) Relationship marketing and organizational cultural change: a multiple case study in dyads. in:

ASSOCIATION OF NATIONAL MEETING OF GRADUATE PROGRAMS IN ADMINISTRATION, 24, 2010, Rio de Janeiro. Anais ..., Rio de Janeiro: ANPAD 2010.

LIEB, R.C.; RANDALL, H. L. (1996) A Comparison of the User of Third-Party Logistics Services by Large American Manufactures, 1991, 1994 and 1995. Journal of Business Logistics, v. 17, n. 1, p. 55-62.

MACHLINE, C. (2011) Five decades of business logistics management and supply chain in Brazil. Journal of Business, v. 51, n. 3, p. 227-231.

MAZZALI L; MILAN, E. S. (2006) Integration Company Customer - Logistics Operator: An Analysis in the automotive chain. Magazine Management \& Production, v. 13, n. 2, p. 353-366. 
SAITO, R.; SILVEIRA, A. D. M. (2008) Corporate governance: agency costs and ownership structure. Journal of Business Administration - FGV, v. 48, n. 2, p. 7986.

SOLOMON, J. (2011) Corporate governance and accountability. John Wiley \& Sons.

VILLENA, V. H.; REVILLA, E.; CHOI, T. Y. (2011) The dark side of buyer supplier relationships: social capital perspective. Journal of Operations Management, v. 29 , n. 6 , p. 561-576.

WILLIAMSON, O. E. (1985) The Economic Institutions of Capitalism: Firms, markets, relational contracting. New York: The Free Press. 


\section{ATTACHMENT}

\section{QUESTIONNAIRE}

\begin{tabular}{|l|}
\hline Name of service provider: \\
\hline www site: \\
\hline Start date of the signing of the contract: \\
\hline Products or services: \\
\hline Completion date: $\mathrm{xx} / \mathrm{xx} / \mathrm{xx}$ \\
\hline
\end{tabular}

To the issues below please tick (X) only one of the options offered

\begin{tabular}{|l|c|l|}
\hline MOST ASPECTS OF COMMERCIAL PARTNERSHIP APPROACH & YES & No \\
\hline $\begin{array}{l}\text { 1. Is of fundamental importance to the understanding of good corporate governance } \\
\text { practices for success and physical proximity to business relationship between the } \\
\text { companies? }\end{array}$ & $($ ) & $($ ) \\
\hline 2. For the service for the interests of commercial partnership be exclusive? & $($ ) & $($ ) \\
\hline $\begin{array}{l}\text { 3. The partnership between computer-based rational design companies that can be } \\
\text { interrupted before the end of the contract in some period? }\end{array}$ & $(\quad)$ & $($ ) \\
\hline
\end{tabular}

To the questions below indicate (indicating with an $\mathrm{X}$ ) which the percentage that most closely matches the condition of commercial partnership relationship between companies including aspects of the value of governance.

\section{ISSUES}

\begin{tabular}{|c|c|c|c|c|c|}
\hline $\begin{array}{l}\text { DRIVERS: MOTIVATORS THAT CONTRIBUTE TO } \\
\text { COMMERCIAL PARTNERSHIP }\end{array}$ & $0 \%$ & $25 \%$ & $50 \%$ & $75 \%$ & $100 \%$ \\
\hline $\begin{array}{l}\text { 1. What is the probability of the partnership have influence only in } \\
\text { the cost presented in the business proposal and aspects of } \\
\text { governance? }\end{array}$ & & & & & \\
\hline $\begin{array}{l}\text { 2. What is the probability of commercial partnership for the service } \\
\text { generate new business in other clients? }\end{array}$ & & & & & \\
\hline $\begin{array}{l}\text { 3. What is the probability of commercial partnership to open new } \\
\text { service provider customers in different segments of the logistics } \\
\text { industry? }\end{array}$ & & & & & \\
\hline $\begin{array}{l}\text { 4. What is the probability of commercial partnership to consolidate } \\
\text { long-term and on up to five (5) years? }\end{array}$ & & & & & \\
\hline
\end{tabular}

Analysis of the aspects and activities that stimulate and sustain the partnership between the companies.

FACILITATORS: ORGANIZATIONAL FACTORS THAT

\section{ENCOURAGE THE DEVELOPMENT OF BUSINESS} PARTNERSHIPS

5. What is the probability of the companies have similar organizational cultures following instruments such as those of ethics, transparency and corporate responsibility?

6 . What is the probability of the partner and the logistic operator have leadership systems and organizational philosophies similar Operational management?

7. What is the probability of the service provider have the same criteria of calculation of KPIs and SLAs Logistic operators

8. What is the probability of the Logistical Operator customer loyalty and consolidate short-term and long-term contracts on commercial partnership?

Analysis of the appearance and activities that stimulate and sustain the commercial partnership between the companies

For the following questions below, indicate only one answer that most closely matches the business relationship between the companies.

9. The breadth of scope of business partnership between companies

( ) $\quad$ a) The commercial partnership can represent only a very small fraction of the business between 
b) The commercial partnership can represent a significant fraction of the business at just one company.

c) The commercial partnership can represent a significant portion of business in both companies.

10. The analysis of the scope of services.

\begin{tabular}{|l|l|}
\hline$(\quad)$ & $\begin{array}{l}\text { a) the commercial partnership is only) for a technical Logistic Operator's operational activity and } \\
\text { covers only one of the plants. }\end{array}$ \\
\hline$(\quad)$ & $\begin{array}{l}\text { b) The commercial partnership may involve various technical operational activities in only one of the } \\
\text { plants. }\end{array}$ \\
\hline$(\quad)$ & c) The commercial partnership involves technical operational activities in various plants. \\
\hline
\end{tabular}

11. The relevance of the commercial partnership between the companies

\begin{tabular}{|l|l}
\hline$(\quad)$ & a) the partnership involves only commercial) activities important to the service provider
\end{tabular}

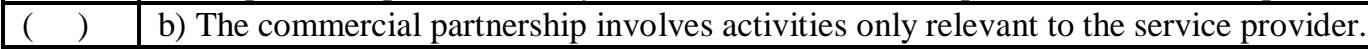

( ) c) the commercial partnership involves only critical activities for both companies,

12. Investments for commercial partnership between companies

\begin{tabular}{|l|l}
\hline ( ) & a) companies don't make investments) sets of low added value
\end{tabular}

\begin{tabular}{l|l}
$(\quad)$ & b) companies make investments in assets sets of low added value
\end{tabular}

\begin{tabular}{l|l}
$(\quad)$ & c) companies are joint investment in assets with high added value
\end{tabular}

13. Investments in information technology to support the commercial partnership

\begin{tabular}{l|l}
$(\quad)$ & a) No prospecting or investments in information technology sets
\end{tabular}

( ) $\quad$ b) For joint information technology investments only in low-value assets

$\begin{array}{lll}(\mathrm{r}) & \text { c) For joint investments in information technologies of high value and regularly }\end{array}$

14. The analysis of the exchange of professionals between service providers and competitors

( ) a) interchanging supplier and competitors that already serves the operator is limited or no longer exists

( ) $\quad$ b) the Exchange and often involves a significant portion of employees or doesn't exist

c) the exchange between supplier and competitors that already serves the following operator contract

15. The analysis of contractual deadlines for consolidation of partnerships between companies

\begin{tabular}{|l|l|l}
\hline$(\quad)$ & a) contracts are short-term and less than 1 (one) year \\
\hline
\end{tabular}

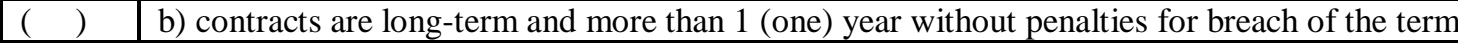

$\left(\begin{array}{l|l}\text { ( ) contracts are specific no link or by reference to the time } \\ \hline\end{array}\right.$

16. Contractual aspects between contractor and hired

\begin{tabular}{l|l}
$(\quad)$ & a) contracts are signed for execution of specific activities
\end{tabular}

$\left(\begin{array}{l|l}\mathrm{l} & \text { b) contracts are signed for general activities without indication specifies operational }\end{array}\right.$

( ) $\quad$ c) the contracts do not specify obligations and common responsibilities just ideologies

17. The analysis of the processes of communication in commercial partnership

\begin{tabular}{|l|l}
\hline$(\mathrm{r})$ & a) are made by representatives of the companies and in handling of specific activities
\end{tabular}

$\left(\begin{array}{ll}\text { ( ) } & \text { b) there are a limited number of official information between service provider and logistics operator }\end{array}\right.$

( ) $\quad$ c) For processes with manual or electronic communication technology between companies

18. Operational aspects in business partnership and communication between companies

\begin{tabular}{l|l} 
( ) & a) Limited and only to meet only the operational activity being executed.
\end{tabular}

\begin{tabular}{|l|l|}
\hline$(\quad)$ & b) Communication is continuously to meet various hierarchical levels between businesses. \\
\hline$(\quad)$ & c) the communication is planned on commercial partnership and at various levels of the companies
\end{tabular}

19. analysis of processes to financial risk and profit sharing

\begin{tabular}{|l|l|l}
\hline$(\mathrm{l})$ & a) there is a low tolerance for losses and losses by enterprises \\
\hline
\end{tabular}

\begin{tabular}{l|l}
\hline ( ) & b) For average tolerance for possible losses and risks among businesses only in the short term
\end{tabular}

( ) $\quad$ c there's high tolerance for) possible losses among the companies, both in the short and in the long run 
ISSN: 2236-269X

DOI: 10.14807/ijmp.v9i1.683

20. analysis to share risks and profits

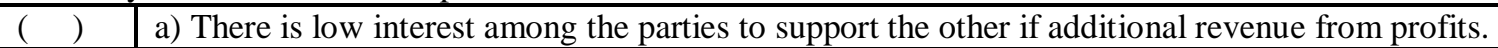

b) There is a high interest among the parties to support the other party to consolidate greater gains.

c) The relationship between commercial support companies to extend the gains are in contract signed. 